\title{
DEVELOPMENT OF LIVING MUSEUM AND STORYNOMIC TOURISM BASED ON TRI HITA KARANA IN KABA-KABA VILLAGE, TABANAN BALI
}

\author{
Made Mutiara Putri Udayani ${ }^{1}$, Putu Eka Wirawan², I Gede Krisna Yoga Putra \\ Pratama $^{3}$ \\ ${ }^{123}$ Institut Pariwisata dan Bisnis Internasional \\ wirawanputu@gmail.com
}

\begin{abstract}
Tourism is currently the sector most affected by the COVID-19 outbreak. However, the momentum of this pandemic is considered a transition period to reorganize Indonesia's tourism. One of them is the development of the tourism sector in the development of tourist villages. The tourism interest that occurred made the author of this study conceptualizes the development of special interest tourism with the concept of living museum and storynomic tourism located in Kaba-Kaba Village, Tabanan, Bali based on Tri Hita Karana. The concept was chosen because Kaba-Kaba Village has a cultural heritage in the form of Puri in which there is an ancient site. This research uses qualitative methods with a data approach through observation in the form of interviews and literature studies. The results showed that the concept of living museum and storynomic tourism is very appropriate for the development of Kaba-Kaba tourist village because tourist products in the form of relics of historical heritage sites become a capital of interest for the development of special interest tourism. With the development of Living Meseum and Storynomic Tourism where Tri Hita Karana as the foundation of cultural tourism can directly fall into the hands of the community where this makes the tourist village that is directly managed by local champions in Kaba-Kaba Village.
\end{abstract}

Keywords: Tourism, Living Museum, Storynomic Tourism, Tri Hita Karana

\section{INTRODUCTION}

Tourism is a sector that is very sensitive to disasters, as is the COVID-19 pandemic that is crippling the global tourism industry. Before the pandemic, the rapid development of the tourism sector had a positive impact and a negative impact that harmed the socio-culture of local communities in a tourism destination. Not infrequently with tourism development, environment, culture, and local wisdom actually experienced degradation. Therefore, the momentum of the COVID-19 pandemic should not only be interpreted as a mere disaster but a transition period to reorganize Indonesia's tourism. The role and synergy of pentahelix stakeholders is vital in reconstructing (recovery) the tourism sector that is 'suspended'. Along 
with that, stakeholders should also diversify products in accordance with postpandemic tourism trends. (Isdarmanto, 2020), sustainable and responsible tourismbased tourism products with authentic value additions will be megatrends in the new normal era. This is in line with (I Made Trisna Semara, Ni Made Ayu Natih Widhiarini, Ni Nengah Ariastini, 2017) stated that the shift in tourist interest in determining tourist destinations gave birth to sustainable tourism development through the development of special interest tourism.

Special interest tourism is a pattern of tourism that emphasizes more awareness and appreciation of the preservation of nature, environment, and culture (environmentally and cultural sensitives) such as traditional art, history and archaeology, and natural aspects in the form of a wealth of flora and fauna, national parks, forests, rivers, lakes and beaches. This aligns with the (UNWTO, 2017), where tourism development must pay attention to the sustainability aspect, namely the balance between economic, sociocultural, and environmental. Kaba-Kaba village is currently being developed into one of the tourist villages in Tabanan Regency. This is evidenced by the Decree of the Regent of Tabanan No. $180 / 329 / 03 / \mathrm{HK} \& H A M / 2016$, which states that Kaba-Kaba Village is a Tourism Village based on community empowerment with principles 1) sustainable, 2) populist, 3) sustainable in creating engaging tourism activities based on culture and Tri Hita Karana as the foundation of cultural tourism in Bali.

Based on the observations, Kaba Village has the potential of a vast and beautiful landscape. Its location in the middle of famous tourist attractions such as Canggu and Tanah Lot makes Kaba-Kaba Village a very strategic village. This village also has Puri Kaba-Kaba, which is stored a wealth of culture, history, and traditions that are very fair and have the potential to be developed towards sustainable special interest tourism. Based on the survey results, the possibility of Puri Kaba-Kaba is not inferior to Puri Saren Ubud and Kertagosa, which have developed first. This is in line with the research of (Oka, Winia, \& Sadia, 2018), which states that the development of tourism in a tourist village aims to develop local potential sourced from nature and socio-culture to contribute to local communities economically and others. Likewise, research conducted by (Putu Widya Darmayanti, I Made Darma Oka, 2017) which mentions that kaba-kaba tourist village problems found there is the quality of local human resources need to be given intensive coaching and training to be able to manage their strengths or potential such as: Natural attractions in the form of rice fields that can be used as trekking and cycling tourism activities. It has a cultural heritage in the form of Puri Kaba-Kaba, which has characteristics different from other tourist villages. The approach taken in previous research is to look at the perspective of the local community with SWOT analysis. Therefore, this research will discuss the direction of the development of Kaba-Kaba tourist village through the concept of a living museum and storynomic tourism. So that not only see the strengths, weaknesses, opportunities, and threats, researchers can formulate the direction of the development of kaba-kaba tourist village.

The development of Puri Kaba-kaba tourism is carried out with a storynomic tourism and living museum approach. Storynomic tourism is a tourism approach that prioritizes narrative, creative content, living culture and uses the power of culture as the DNA of the destination. The purpose of storynomic tourism 
is not only enjoying the beauty of nature, this concept is also expected to make tourists know the story behind the destination so that tourists can visit longer, 2) exploration of tourist areas to the maximum, 3) gain new knowledge and experience, 4) provide testimonials or recommendations to others. It is also in line with the concept of living museum that prioritizes activities that reflect local behavior and wisdom in Puri Kaba-Kaba so that tourists will not only listen to historical stories, but can also be actively involved in Balinese cultural activities that prioritize the concept of Tri Hita Karana, which is a harmonious relationship with God, humans, and the environment.

The concept of storynomic tourism is a tourism communication approach that prioritizes narrative, creative content, and the power of history and culture (McKee, Robert, 2018). Currently, the Ministry of Tourism and Creative Economy promotes this concept in one of Indonesia's tourism development and promotion strategies. Kaba-Kaba village still exists with the identity of the "oldest village" in Kediri Subdistrict, with the discovery of ancient sites whose spiritual energy remains "alive" today. These ancient sites have the beliefs of Buda and Shiva Bhairawa, who became the forerunner of this village. In his research also mentioned that the tourism potential owned by Kaba-Kaba Village is very unique, namely in the form of a cultural heritage that has the potential to be used as an icon of cultural tourism development coupled with the cultural traditions of the local community that are still very strong and maintained.

(Putu Widya Darmayanti, I Made Darma Oka, 2017) mentions that cultural heritage or ancient sites in Puri Kaba-Kaba are still functioning correctly and are believed by the community to be able to protect their lives. These sites are also a competitive advantage to sell to tourists. The use of famous stories and characters as trademarks shows that literature can be an effective source of branding. The popularity of folklore and its characters can immediately make the products that choose it becomes a brand that the public can quickly know. Branding folklore or literature is important because of its popularity and seen from the representation of cultural elements implied in the branding. The study also included examples of application in the villages of Bali Aga in North Bali, and there are much folklore developed to attract tourists. One of the folklore is titled "Bale Gajah Tumpang Salu" as a story to explain the unique architecture of the Balinese house Aga (Original Balinese). From the story shown to be part of the tourist attraction, tourists can see the architecture of traditional Balinese Aga houses different from Balinese dwellings in general. In the process, the residents of Bali Aga gradually began to associate folklore with activities they usually do, such as inviting tourists to enjoy palm sugar and invited to make and see the process of making it. So it can be concluded that the utilization of folklore has an enormous contribution to the improvement of the community economy through tourism in the form of the concept of "storynomics" which also has another positive impact that can preserve existing folklore.

In addition to the development of storynomic tourism, which has the potential to be applied in the framework of tourism development in Kaba-Kaba Village, there is a concept called a living museum. In research from (StylianouLambert, Boukas, \& Christodoulou-Yerali, 2014) said to be a reference for the establishment and management of museums in the future, where the surrounding 
environment and daily sociocultural life become an inseparable part of the museum's existence (Couteau, Jean, 2013). The development of a tourist attraction using the living museum concept can also act as a means that can directly introduce its growth and development and become the preservation of socio-cultural life in an area.

Previous research has been conducted by (Muliadi \& Suryasih, 2016) with the title Arma Museum Management As Cultural Tourism Attraction In Ubud Village In this study, it was explained that the management of the Arma Museum was viewed from the point of view of cultural resource management, which was reflected in the utilization of cultural arts aspects to preserve these cultural resources. If it is associated with the potential of Kaba-Kaba Village, it is supported by the existence of Puri Kaba-Kaba, which can be developed into a living museum by involving local wisdom or local activities of the village community, which is still very strong and rich in culture

\section{METHODOLOGY}

The research location is in Kaba-Kaba Village, Kediri District, Tabanan Regency, Bali. This research is descriptive research with a qualitative approach. According to (Sugiyono, 2016) qualitative descriptive method is a research method based on the philosophy of post positivism used to examine the condition of natural objects (as opposed to experiments) where the researcher is the key instrument of data collection techniques carried out by trigulation (combined), data analysis is inductive/qualitative, and the results of qualitative research emphasize meaning rather than generalizations. This study obtained data with an approach through the observation method by going directly to the research location, interviews, and by adding theory to the study of literature from various sources. Overall information and data were obtained by interviewing community leaders.

The selection of informants was not determined, but the researchers used a snowball sampling system, which means the researchers interviewed one community leader (Tetua Puri Gede Kaba-Kaba) and then searched for other informants based on the instructions of previous informants and so on. If data retrieval and information are sufficient and seem monotonous, the data collection will be stopped. Furthermore, the data is processed using qualitative descriptive. According to (Arikunto, 2019), descriptive research is intended to investigate the circumstances, conditions, or other things mentioned, the results of which are presented in a research report. These researchers process and interpret the data that has been obtained from the results of observations, interviews and literature studies.

\section{RESULTS AND DISCUSSION}

\section{RESULT}

Kaba-kaba Village is a village that is currently being developed into a tourist village in Tabanan Regency. This is evidenced by the issuance of the Decree of the Regent of Tabanan No. 180/329/03/HK\&HAM/2016 which states that Kaba-Kaba Village is a Tourism Village based on community empowerment. Based on observations, 
Kaba-kaba Village has the potential for a vast and beautiful landscape and its location amid famous tourist attractions such as Canggu and Tanah Lot makes Kaba-kaba Village one of the most strategic tourist villages. In addition to having extraordinary natural potential, Kaba-kaba Village also has the potential for human resources, most of which are the younger generation or productive age groups who have the potential to become local champions in their village so that the development of castle tourism can take sides and have a positive impact on the local community. This village also has Puri Kaba-kaba, which contains a wealth of culture, history, and traditions that are very valuable and have the potential to be developed towards sustainable special interest tourism. Based on the results of a survey conducted, the potential of Puri Kaba-kaba is not inferior to Puri Saren Ubud and Kertagosa, which have already developed. However, in its development several obstacles were found that made the existence of Puri Kaba-kaba not exist like the existence of other castles in Bali.

\section{DISCUSSION}

The biggest obstacles faced today in the context of developing the Puri Kaba-kaba tourist attraction are the lack of understanding of the younger generation in Kaba-kaba Village in telling the history and unique architecture and artifacts of the castle, the absence of more engaging supporting tourism activities, and the absence of cooperation with travel. Agents and the absence of a website as a means of marketing castle tourism in Kaba-kaba Village (AA Ngurah Anom, 2021). In line with this, the development of the cultural industry (heritage industry) in Indonesia has been driven by international organizations, such as UNESCO, and national and local organizations with agendas with perspectives outside the area where the cultural heritage is located. In addition to developing tourism products based on sustainable and responsible tourism, the trend of heritage tourism is also developing with historical objects such as Puri Kaba-kaba.

Therefore, developing the Puri Kaba-kaba area through a living museum approach and storynomic tourism is very suitable and strategic to be developed. A living museum, or another term called a living museum, is part of the new museology. A living museum is an area or place that shows the life of history and art in the past which can be seen directly or live as in the past (Saraswati, Adrianus, Day, Kristen, \& Wacana, 2004). The philosophy contained in ancient sites or artifacts in Puri Kaba-kaba, if packaged attractively, will be economically beneficial because the story or philosophy has been processed into storynomics so that it can be used as tourism branding. Meanwhile, storynomic tourism is a tourism approach that prioritizes narrative, creative content, living culture and uses the cultural power of the destination DNA. In other words, the storynomic tourism approach is how to package the beauty of the charm of a tourist attraction in an interesting story, so that it becomes an attraction for tourists to visit.

Several iconic and unique sites add value to promoting Puri Kaba-kaba through storynomic tourism. Where in Kaba-kaba Castle there are several ancient sites and artifacts, namely the Yama Raja statue, which is placed on the altar which is surrounded by natural stone in each corner, in the chest there is a square divided into nine squares. Where in each box there is an inscription of the holy letter as an indicator of the cardinal directions. Based on observations, the Yama Raja statue is 
believed to be a place to ask for protection, welfare and authority for the entire region and community in Kaba-kaba Village. In addition, in the castle there is also a statue of Dewa Megelut which resembles a statue of a man and a woman in a sitting posture hugging which believed by the community as a place to ask for fertility for married couples who do not have children. Besides these statues, many ancient sites have interesting stories or philosophies to know more about.

Balinese cultural tourism is Balinese tourism which is based on Balinese culture inspired by Hinduism and the Tri Hita Karana philosophy as the main potential by using tourism as a vehicle for its actualization, to create a harmonious relationship between tourism and culture that makes both of them develop synergistically and can provide prosperity to society, cultural and environmental sustainability. Knowing the tourism potential of Puri Kaba-kaba, which is extraordinary and interesting to be packaged as a tourist attraction through a living museum approach and storynomic tourism, the direction of developing Puri tourism is also based on the philosophy of Hindu life. Tri Hita Karana is a Balinese philosophy of life that contains three elements that build a balanced and harmonious relationship between humans and God, humans and humans and humans and their environment, which is a source of prosperity, peace, and happiness for human life. The people of Kaba-kaba Village strongly adhere to this philosophy as contained in implementing cultural tourism in Bali.

Based on the explanation above, the researchers carried out community empowerment carried out in Kaba-Kaba Village. There are several activities carried out, namely human resource training. Kaba-Kaba Village, which has become one of the tourist villages, can compete with other tourist attractions in terms of natural, cultural potential, and the quality of its human resources. Some of the training carried out were local guide training, sewing, yoga, meditation, and cooking class training. In the activity, the researchers invited and collaborated with several institutions to provide training to the community. The community is divided into several groups that have been determined by the Pokdarwis (Tourism Awareness Group) of Kaba-Kaba Village. Where each group will take part in the training held. In local guide training, the community is fostered and accompanied by several language lecturers from the Institute of Tourism and International Business to become professional tour guides and in accordance with existing standards, understand foreign languages, and have good communication skills. So that later when tourists visit Puri Kaba-Kaba, the community is ready to go around with tourists to explain the existing attractions with all the stories or philosophies behind every ancient site in Puri Kaba-Kaba. Then in the mejejahitan training, the researchers embraced the women in Kaba-Kaba Village to learn to make canang and understand the philosophy or meaning of each type of canang made. Where canang itself is an offering in Hinduism, these types of canang is an offering that is said to be quite simple in Bali. Then the next training is yoga and meditation training. In training, researchers collaborated with an institution with certified yoga instructors to share their insights about yoga and meditation with the people of Kaba-Kaba Village. The last training is cooking class training which will be one part of the tour package at Puri Kaba-Kaba. The types of dishes made are typical Kaba-Kaba culinary, namely Lawar, Komoh, and Gecok. People who participate in the training are accompanied by a Junior Indonesian Chef who helps the community 
know good and correct cooking techniques and how to explain or tell the meaning of the dishes made to tourists. From several trainings carried out in order to foster the people of Kaba-Kaba Village, it is known that the community is very enthusiastic and their contribution is enormous in participating in the training held. The number of participants attending the training is constantly increasing.

\section{CONCLUSION}

From the results of the discussion that has been described, it is concluded that the analysis results are in the form of qualitative data through an observation approach with interviews and literature studies as a source of information used. It is concluded from the results of the discussion that the development of the Living Museum and Storynomic Tourism with the Tri Hita Karana concept is a very appropriate concept for tourism development in Puri Kaba-Kaba located in KabaKaba Village, Tabanan. Wherewith tourism products in the form of relics of historical heritage sites, it becomes capital of interest to develop special interest tourism. The development carried out also carried out approaches and training for local champions in Kaba-Kaba Village. With the path to local champions, the development of Puri Kaba tourism is maximized because it is directly managed by the people themselves. The community can directly convey cultural and heritage tourism in Puri Kaba to a broader community, namely domestic tourists and foreign tourists. With the development of the Living Museum and also Storynomic Tourism where Tri Hita Karana as the foundation of cultural tourism can be directly managed into the hands of the community, this makes a tourist village that is directly managed by local champions in Kaba-Kaba Village.

\section{ACKNOWLEDGMENT}

This research supported by the Minister of Education and Culture Indonesia in the Holistic Program of Village Development and Empowerment (PHP2D), The Institute of Tourism and International Business also supported by the Bachelor Tourism Program, Head of the Tourism Study Program, Head of the Research and Community Service Institute of the Institute of Tourism and International Business.

\section{REFERENCES}

Arikunto, S. (2019). Prosedur Penelitian. Jakarta: Rineka Cipta.

Couteau, Jean, W. W. (2013). Gung Rai: Kisah Sebuah Museum. Kepustakaan Populer Gramedia.

I Made Trisna Semara, Ni Made Ayu Natih Widhiarini , Ni Nengah Ariastini, dan N. L. S. M. (2017). Strategi Pengembangan Kawasan Budidaya Rumput Laut Sebagai Wisata Konservasi dan Edukasi Berbasis Masyarakat di Pantai Pandawa, 7(2), 147-158.

Isdarmanto, I. (2020). Strategi Branding Pengembangan Industri Pariwisata 4.0 Melalui Kompetitif Multimedia di Era Digital. Journal of Tourism and 
Creativity, 4(1), 1. https://doi.org/10.19184/jtc.v4i1.14383

McKee, Robert, T. G. (2018). Storynomics: Story-driven marketing in the postadvertising world. Hachette UK.

Muliadi, I. N., \& Suryasih, I. A. (2016). Pengelolaan Museum Arma Sebagai Daya Tarik Wisata Budaya Di Desa Ubud. Jurnal Destinasi Pariwisata, 4(2), 58. https://doi.org/10.24843/jdepar.2016.v04.i02.p11

Oka, I. M. D., Winia, I. N., \& Sadia, I. K. (2018). Pemetaan potensi pariwisata dalam mendukung pengembangan pariwisata di Desa Serangan. Bhakti Persada, 4(1), 47-54.

Putu Widya Darmayanti, I Made Darma Oka, I. W. S. (2017). Pengembangan Desa Wisata Kaba-Kaba Dalam Perspektif Masyarakat Lokal. Bumdes.Id, 11(01), 27-31. Diambil dari https://bumdes.id/wp-content/uploads/2018/01/PaparanPengembangan-Desa-Wisata-Kementerian-Pariwisata.pdf

Saraswati, T., Adrianus, M., Day, R., Kristen, U., \& Wacana, D. (2004). Kampung Adat Deri Kambajawa di Kabupaten Sumba Tengah Sebaga Living Museum. Seminar Nasional Arsitektur dan Tata Ruang (SAMARTA), Bali-2017, 1-10.

Stylianou-Lambert, T., Boukas, N., \& Christodoulou-Yerali, M. (2014). Museums and cultural sustainability: stakeholders, forces, and cultural policies. International Journal of Cultural Policy, 20(5), 566-587. https://doi.org/10.1080/10286632.2013.874420

Sugiyono. (2016). Metode Penelitian Kuantitatif, Kualitatif dan R\&D. Bandung: PT Alfabet.

UNWTO. (2017). UNWTO Tourism Highlight 2017 Edition. 